\title{
Internal marketing for engaging employees on the corporate responsibility journey
}

\author{
Isabel Sanchez-Hernandez ${ }^{1}$, David Grayson ${ }^{2}$ \\ ${ }^{1}$ Universidad de Extremadura (Spain), ${ }^{2}$ Cranfield University (United Kingdom) \\ isanchez@unex.es, david.grayson@cranfield.ac.uk
}

Received November, 2011

Accepted June, 2012

\section{Abstract}

Purpose: The purpose of this paper is to explore whether internal marketing could be a powerful tool for engaging employees on the corporate responsibility journey.

Design/methodology/approach: In the absence of empirical work linking internal marketing efforts in organizations and employee engagement in corporate responsibility issues, a conceptual approach based on literature review is carried out to determine the existing possibilities provided by internal marketing to enhance corporate responsibility.

Findings: Reflexion from the extant literature indicates that, because employee engagement matters, internal responsibility should be put first. The internal marketing umbrella, including "selling internally" the idea of responsibility, facilitating internal communication, enhancing corporate volunteering or the possibility to become a social intrapreneur, could help to align employees' needs with corporate responsibility goals.

Practical implications: The results suggest that managers must ensure that internal aspects of management, such as internal communication and employee commitment are taken into account in order to get success in corporate responsibility issues. Managers need to be more proactive trying 
to introduce the marketing function in human capital issues. Understanding employees' wants and needs and selling internally responsibility goals would make external efforts in developing a responsible strategy much more likely to succeed.

Originality/value: Reflecting the literature which highlights the importance of internal marketing, we pay particular attention to their role on promoting corporate responsibility internally. The results indicate that while organizations strive to achieve corporate responsibility goals, it is expected that effectiveness will be greater among organizations using internal marketing tools for this purpose. To the best of our knowledge is the first time this relationship has been academically discussed offering recommendations for practitioners.

Keywords: internal marketing, internal market orientation, engagement, corporate responsibility

Jel Codes: M14, M50

\section{Introduction}

Corporate responsibility (CR) is gaining currency around the globe. The concept involves creating innovative and proactive solutions to societal and environmental challenges, as well as collaborating with both internal and external stakeholders. While we could say that $\mathrm{CR}$ is definitely on the agenda of most competitive organizations, there remain significant challenges concerning how to embed CR into everyday processes and cultures (Bartlett, 2009). One of these challenges is engaging employees on the CR journey.

CR can be strategic and considered like any other profit-optimizing strategy. For both academics and practitioners, the altruistic and strategic views about the purpose of CR coexist. Recent studies attempt to integrate the concept of CR and corporate strategy (Galbreath, 2006; Bies, Bartunek, Fort \& Zald, 2007; Maxfield, 2008), suggesting the use of the same framework that guides the core business choices to make CR a source of competitive advantage for the firm (Porter \& Kramer, 2006). Bagnoli and Watts (2003) assert that firms with good corporate citizenship strategies are conducting a profit-maximizing business. Recently, Fernandez-Kranz and Santaló (2010) have empirically demonstrated that 
companies in more competitive industries have better ratings because $\mathrm{CR}$ is driven by strategic considerations independently of any additional altruistic motivation.

Involving stakeholders in corporate strategies is considered a good policy which provides companies with competitive advantages (Walsh, 2005). In this sense, employee integration in CR, as relevant internal stakeholders, should be evaluated as a strategic capability for the organization (Sharma \& Vredenburg, 1998). Sharp and Zaidman (2010) have observed a tendency for more and more participation by employees in CR activities as a part of their obligations as employees. This is interpreted as an indication of the penetration of $C R$ values into the organizational culture of these companies, and symptomatic of the success of the process by which the CR strategy is integrated into their organizational behaviour (Were, 2003; Bhattacharyya, 2010). As such then, it seems to us that companies who want a suitable strategy for implementing the idea and the challenges of CR could develop and put into practice an internal marketing (IM) plan to help engage employees in CR.

IM was first proposed as a way to deliver high levels of quality in service industries (Berry, 1981; Grönroos, 1981), nowadays it is considered a paradigm of organizational change, management and implementation strategies (Ahmed \& Rafiq, 2002). IM has a role to play in CR strategies because it can reinforce and emphasize the process of transforming an organization into a responsibility-focused entity.

From a critic's position, Fonteneau (2003) argues that the only way to legitimize and lock-in the trust of citizens in companies is to consider employees' rights and needs in the first place. It is important to remark upon a very simple and underlying idea supporting the link between $\mathrm{CR}$ and IM: to build trust and commitment in society, any organization must intimately know and understand its people and itself (Clarkson, 1995; Ahmed \& Rafiq, 2003; McBain, 2007). In our opinion, there are no contradictions in pursuing and aligning organizational goals and employees' goals. Based on the Total Quality Management thinking (Barnes \& Morris, 2000) the IM virtuous cycle is simple: by satisfying and motivating employees an organization should be in a better position to generate a higher quality of service, higher levels of customer satisfaction, and higher productivity and profits (Ahmed \& Rafiq, 2003). Empirical results demonstrate that a significant relationship exists between IM efforts and organizational performance (SanchezHernandez, 2008; Sanchez-Hernandez \& Miranda, 2011).

Although the usefulness of IM is recognized by academics and practitioners, some 
critics claim that the term is just a new synonym for good human resources management but IM is not a label. Ahmed and Rafiq (2002) have clarified that IM is the use of marketing-like techniques such as segmentation, market research and marketing mix to motivate employees towards organizational goals. They have delimited the boundary between human resource management that is empowered to use formal mechanisms thanks to the contractual nature of employment, and IM by using a definition supported by Kotler (1972) who states that marketing consists of persuasive actions (non-coercive) to induce positive responses in other social units. Thus, IM and human resource effectiveness are distinct. The study of Ewing and Caruana (1999) provides empirical support to demonstrate that IM implies the co-ordination of human resource management and it is an important antecedent to human resource effectiveness.

In this study, we build on this emergent research by examining whether IM could be a powerful tool for engaging employees on the CR journey. We organize the remainder of this article as follows: in the following sections, we provide a conceptual background and define the research topics under investigation. Next, we develop the model specification we use to model the relationship between IM and CR. We conclude by discussing the implications of our findings.

\section{Corporate responsibility conceptualization}

In academic contexts and business environments hundred of definitions have been proposed referring to a more responsible way of doing business. In the well known Carroll's conceptualization (Carroll, 1979) the CR of business entails the simultaneous fulfillment of the firm's economic, legal, ethical, and philanthropic responsibilities. Stated in managerial terms, the responsible firm should strive to make a profit, obey the law, be ethical, and be a good corporate citizen. Carroll revisited his four-part definition of $\mathrm{CR}$ and organized the notion of multiple responsibilities in a pyramid construct (Carroll, 1991). His revised conceptualization implies that the four responsibilities are additive. From this perspective, economic and legal responsibilities are mandatory, ethical responsibility is socially expected, while philanthropy is socially desired.

The conceptualization offered by Wood (1991) constitutes a significant advance in $\mathrm{CR}$ research considering the principles that motivate a firm's social responsibility actions at three levels of analysis: principle of legitimacy (institutional level), organizational sense of public responsibility (organizational level) and choices of managers and their personal preferences (individual level). 
Clarifying the boundaries of CSR, Bloom and Gundlach (2001) define it as "the obligations of the firm to its stakeholders-people and groups who can affect or who are affected by corporate policies and practices. These obligations go beyond legal requirements and the company's duties to its shareholders (Bloom \& Gundlach, 2001: page 142).

Freeman's classic definition of a stakeholder is "any group or individual who can affect or is affected by the achievement of the organization's objectives" (Freeman, 1984: page 46). This paper assumes The Stakeholder Theory of the firm expressed in the new European Union definition that says CR is the responsibility of enterprises for their impacts on society" (European Commission, 2011: page 6). CR is about minimizing negative environment, social and economic impacts and maximizing the positive impacts. In our opinion, it is a timely and welcome definition in the midst of the Euro-zone crisis. The definition emphasized that is about core business purpose and strategy and how business makes all its money, and not how it spends a small fraction of it in the community. Because CR requires engagement with internal and external stakeholders, it enables enterprises to build long-term consumer, citizen and employee trust as a basis for sustainable business models.

\section{Marketing and internal marketing: Conceptualization, criticism and evolution}

Marketing is a relatively new discipline in management. Over the last 100 years it has travelled through several stages (Wilkie \& Moore, 2003): its "beginnings" in the 1920; formalization in the 1950s when marketing emerged as a discipline; deviation from the paradigm in the 1980s; and now intensification and fragmentation of deviation. The discipline of Marketing does now relate to areas that originally had only been marginally touched by Marketing: moving from interest in the product to concern for services, from transactions to relations, from the manufacturing process to value creation, from focusing on human and material resources to concern for knowledge-based resources (Webster, 2005; BouzasLorenzo, 2010).

It is recognized in today's turbulent business environment that marketing has become increasingly important as a business function in spite of some remaining negative images represented by the "4Ms" approach described by Chapman and Cowdell (1998): misinterpreted, misused, misunderstood, and miscast.

Since the first narrow definition of marketing published by the American Marketing 
Association (Gundlach, 2007) as the performance of business activities that direct the flow of goods and services from producers to consumers, to the last definition published in 2007 which considers marketing as the activity, conducted by organizations and individuals, that operates through a set of institutions and processes for creating, communicating, delivering, and exchanging market offerings that have value for customers, clients, marketers, and society at large (AMA, 2007), great efforts have been made in the literature to extol the virtues of marketing.

Modern marketing goes beyond the first definition and has, and continues to, evolve to a more humanistic and interactive approach where companies offer capabilities and make propositions but it is the customer that creates value. The first conception has been eclipsed and the big talking point today could be cocreation and service dominant logic (Vargo \& Lusch, 2004; Gummesson, Lusch \& Vargo, 2010).

Marketing as a discipline has faced some negative connotations and subsequent evolutions in the eyes of other management academics, and the evolution of citizens as consumers seen in marketing needs to be replicated in the IM framework. The most important barrier for IM could be - surprisingly - traditional commercial marketing. If one makes the parallel between IM and the 1935 definition of Marketing, there is the risk of objectifying employees, treating them as things to be managed by appropriate marketing mixes derived from segmentation techniques. IM should be considered in the light of the AMA (2007) definition of Marketing. However, the new marketing paradigm is stakeholder oriented rather than merely consumer oriented (Girod, 2005). Simmons (2009) proposes that the paradigm shift in marketing has implied an integrated stakeholder-accountable marketing approach that recognizes employee expectations of a more socially responsible approach. Relationship marketing (Sirgy \& Lee, 2008) seeks long-term and mutually beneficial relationships with external and internal stakeholders (including employees as a key constituency). Thus, IM needs to be considered in this manner - not as a tool to objectify employees, rather to engage employees in an interactive relationship aligning individual and corporative goals.

Koch and McGrath (1996) suggested firms that develop effective routines for acquiring human assets develop a stock of talent that cannot be easily imitated. According to the resource-based view of the firm (Wernerfelt, 1984; Prahalad \& Hamel, 1990; Barney, 1991), the ability of a firm to perform better than its competitors depends on the unique interplay of human capital, organizational and 
physical resources over time. Following this approach, IM should be used as a human capital strategy for developing internal competencies for external success (George, 1990). According to Ahmed and Rafiq (2003) IM links the employee to strategy. Fernandez, Montes and Vazquez (2000) refer by human capital to the knowledge acquired by employees who increase their professional qualifications, their productivity and the value of their contribution to the organization. IM should link CR strategy to developing competencies, which are in turn linked to each individual's intelligence, creativity, responsibility and experience. By so doing, IM works by bringing the individual into the collective (Ahmed \& Rafiq, 2003).

The growing strategic importance of IM in business management is well documented. Although IM is a concept in evolution, one of the most comprehensive definitions, which emerged from a synthesis of the most important contributions over recent years, is proposed by Ahmed and Rafiq (2002: page 10): "Internal marketing is a planned effort using a marketing-like approach directed at motivating employees, for implementing and integrating organizational strategies towards customer orientation".

Clearly, the scope of IM activity is much wider than simply the motivation of employees. This conceptualization emphasizes the need to generate crossfunctional coordination efforts to accomplish customer-satisfaction objectives. The essence of IM is based on those activities which improve internal communications and customer-consciousness among employees, and the link between these activities and external market performance (Ballantyne, 1997).

\section{Understanding internal marketing for corporate responsibility purposes}

IM has been developed directly from conventional marketing theory (Woodruffe, 1995). It is based on the assumption that the accumulated knowledge of the marketing function can be used within the organization itself in order to gain competitive advantage in the market as well. Derived from general marketing assumptions (Kotler \& Amstrong, 2008; Kotler \& Keller, 2012), active IM programmes are concerned with:

- Identifying the nature of employees' needs and wants, and how these needs can be satisfied by the organization through the development of human resources policies.

- Identifying how the needs of different groups of employees differ. 
- Deciding how the organization can structure itself to enable it to differentiate itself from its competitors and became an employer of choice, attracting and retaining the best talent available in the labour market.

This mix of activities relating to active marketing inside the company is described as the IM mix or "the 4Ps of IM": product, price, place and promotion. Based on previous contributions (Bansal, Mendelson \& Sharma 2001; Arnett, Laverie \& McLane, 2002; Ahmed \& Rafiq, 2002), our definition of IM for CR purposes is: "Any planned effort to align, motivate and integrate employees towards the effective implementation of corporate responsibility and the organization's sustainability strategy". Based on this definition, we can say that IM is able to develop dynamics capabilities defined as recombination of resources into new organizational and strategic routines considered new sources of competitive advantage (Teece, Pisano \& Shuen, 1997).

Figure 1 shows our application to CR strategy of the multi-level model of IM developed by Ahmed and Rafiq (2002). The model represents how traditional marketing tools and techniques can be used internally to generate employee engagement and effective CR strategy implementation inside the company.

The original model is built on three strategic levels. The first level, called Direction (remembering that traditionally, CR strategy uses a top-down approach), requires the development of the general agenda to be deployed. It is concerned with setting the objectives and defining the direction in which organizational efforts to became responsible are to be directed. This requires the evaluation of external opportunities and the analysis of organizational capabilities. Although this approach is probably essential in beginning to raise CR awareness and achieve progress in companies, it nonetheless seams insufficient in achieving further sustained improvements. Real improvements should require the implementation of employee empowerment programs as considered in the last level.

The second level, called Path, is concerned with the consideration and specification of alternative ways to implement the CR strategy and the detection of barriers and the mechanisms for overcoming them. In this level, specific programmes must to be created for particular groups of employees. Internal market research, segmentation and positioning are powerful marketing tools in order to achieve effective implementation. The third level, called Action, is the translation of decisions into activities. At this level the aim is to create a tactical package of actions fulfilling employee needs. It involves providing an appropriate mix of differentiated benefits to specific employees segments that will motivate them to 
achieve effective implementation of CR strategy.

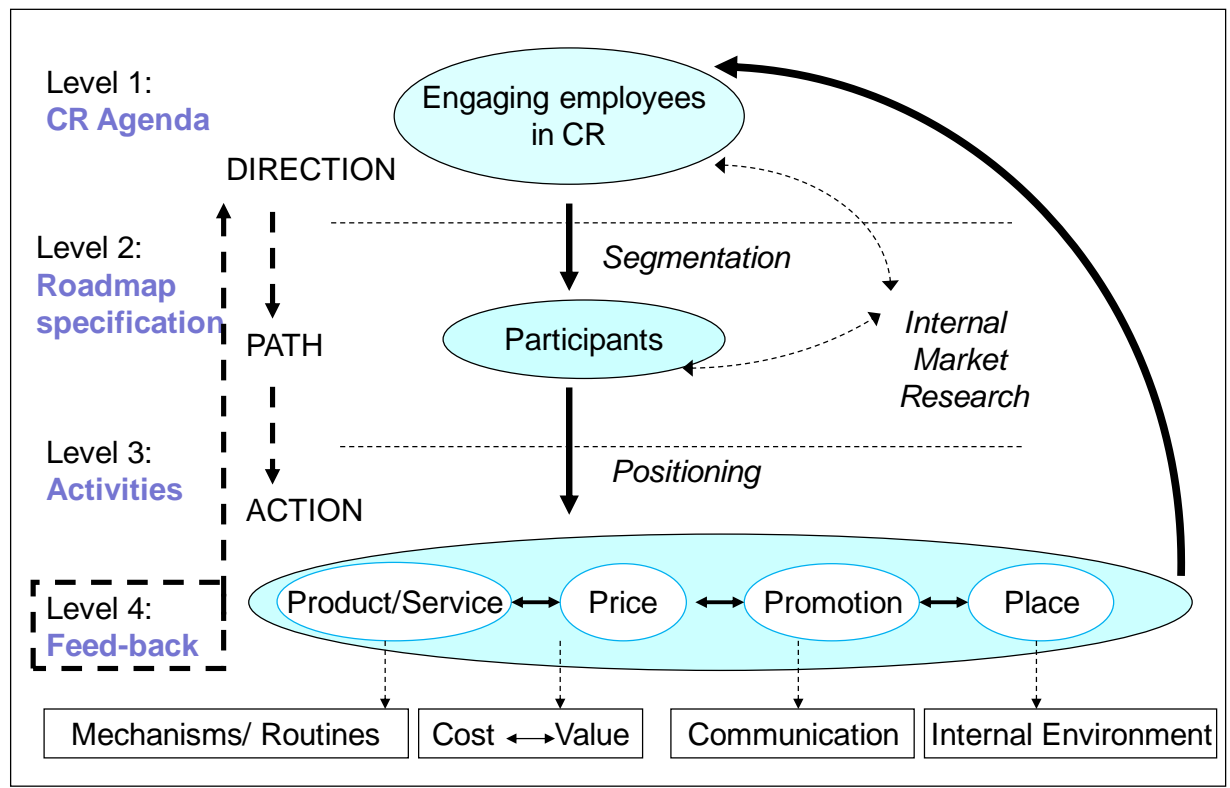

Figure 1. Model of IM for CR Employee Engagement. (Adapted from Ahmed \& Rafiq, 2002)

Nowadays, CR and sustainability seem to need both top-down and bottom-up efforts to get the best out of organizations (Grayson, 2010). Considering that, we have added a fourth level, called Feedback, which represents voluntary employees' contributions to $C R$ and creative initiatives developed by social intrapreneurs. It is a new focus, a complementary approach to the traditional framework to understand CR strategy. It represents, and recognizes the possibility to promote CR from down, (the base of the organizational pyramid), to the top, creating a synergic interaction with formal CR programs managed from the Direction.

The model also deploys the marketing mix concept developed by McCarthy (1960) to the IM context as it was firstly offered by Piercy and Morgan (1991) and extended later by Ahmed and Rafiq (1993). This paper develops the basis for adapting key marketing mix elements for creating successfully an IM plan to engage employees in CR.

\section{Internal products suitable for engaging employees with CR}

In external marketing, a product is anything that companies can offer to their markets to satisfy a want or need. In the simplest conceptualization, an internal product is the job (Collins \& Payne, 1991). Treating jobs as products means going beyond tasks that need to be performed and giving consideration to factors other than financial remuneration. It means also considering training needs, levels of responsibility, involvement in decision-making, career opportunities and the 
working environment (Ahmed \& Rafiq, 2002). Managers must create an internal product which engages employees in the organization's CR and sustainability philosophy. In our opinion, without a "good internal product" focus on improving employees' quality of life, there is limited hope of engaging employees with the idea of investing time and effort in CR issues.

Improving employees' quality of life has become a strategic issue related to being an employer of choice and managing company sustainability. The notion of sustainability has become increasingly popular also in the field of Human Resources Management (HRM) and it has recently been considered a new paradigm for HRM and talent management (Boudreau \& Ramstad, 2005). The World Commission on Environment and Development on the Brundland Report defined sustainable development as a "development that meets the needs of the present without compromising the ability of future generations to meet their own needs" (WCED, 1987: page 43). This definition has been concerned with the question of how organizations deal with economic, social and environmental resources and go beyond "the triple bottom line" (Elkington, 1998). According to this approach, to be sustainable organizations need to take actions to ensure that they contribute to the sustainable management of human resources, as well as contribute to the wellbeing of society as a whole.

We highlight two ways for creating a good internal product by improving employees' quality of life: first, developing better internal products and services and second, ensuring the internal policy is aligned with external marketing.

Developing new products or services is a current issue in marketing concerning product decisions. A new internal product for engaging employees in CR should consist of changing from traditional reward systems, typically financial and easily copied by competitors, to total reward system compensation, embracing everything that any employee values in the employment relationship (Towers Perrin, 2007). The core idea of total reward system compensation is that compensation is not just about money (Kaplan, 2007). The challenge, especially now in a time of global economic crisis, is to develop creative reward packages to retain the best staff members and to engage them in a CR strategy that keeps people focussed, even if they could earn more money working for other companies (BITC, 2009). In fact, nowadays few of the traditional reward elements can be offered, such as life-time employment and career development for all employees, international assignments and rock-solid pensions for top-level employees. So, constructing a new offer based on opportunities to contribute to CR and sustainability is a good alternative. 
Some basic aspects to be considered in this creative reward package are suggested as follows:

- Job design. Companies embracing broader roles rather than narrowly defined job descriptions are creating a more flexible workforce able to develop citizenship behaviour in their day-to-day jobs and adapt to new requirements resulting from $\mathrm{CR}$ demands.

- Learning opportunities. The acquisition of new skills related to CR as well as the enhancement of existing ones can act as a powerful reward tool, both personally and professionally. A good example is learning how to manage the time at work to achieve the goals in order to get extra-time for social purposes collaborating with the community in corporate volunteering programs, for instance. Achieving much more with the same time and learn how to be organized taking control of the day should be good for the employee and for the company too.

- Integrating rewards with recognition premiums for the best corporate citizenship behaviour in the company.

- Creating a smart work environment. On the one hand, flexible work and tele-working, sabbaticals or career breaks when possible, and community volunteer opportunities provide an opportunity for employees to embrace CR principles and enhance employees' commitment to their organization. On the other hand, it allows employers to differentiate themselves from their competition.

In addition, we want to highlight some radical aspects to innovative reward packages to enhance $\mathrm{CR}$ based on generating opportunities to make suggestions and to contribute proactively. We focus on the three possibilities of becoming a volunteer sustainability champion, opportunities to serve on green teams and the freedom to become a social intrapreneur:

- Sustainability champion. The sustainability champion is a volunteer encouraged to feed into and support the sustainability strategy with any ideas, suggestions and even complaints regarding the responsible performance of the company (Exter, 2009).

- Green Teams. Organization design for CR purposes should take into account flexible structures. It might be better to follow the organic design approach, characterised by low formalization and centralization and high integration. 
However, in the field of organizational design, relevant authors such as Mintzberg (1979) have suggested that significant organizational change does not occur in small stages. In our view, the changes needed in order to become a responsible and sustainable company need configurational changes in organization design to support them. The implementation of green teams is an important contribution to this. While in traditional companies management teams consist exclusively of those that create revenue, when companies engage in $\mathrm{CR}$, management teams are also comprised of those with the primary responsibility for creating $C R$ value (Austin \& Reficco, 2009). Green teams have been defined as participative and interdepartmental, able to unlock new ideas, innovation and creativity in order to attain greater environmental excellence in the move towards sustainable business operations (Beard \& Rees, 2000). Ackerman, Helliwell, Nisenson, Pattinson, Latimer and Quevedo (2010) have identified the key factors for the successful evolution of green teams in generating enterprise value and sustainable business transformation as: strong executive support, close alignment with the company's sustainability goals, the presence of a centralized leader, high diversity amongst team members and systems for creating, measuring and tracking initiatives. Successful green teams are able to "sell" market environmental benefits to all other departments (Beard \& Rees, 2000), thus creating a sustainable network across the company to pursue the best practicable environment options.

- Social intrapreneurs. The CR journey can be powered by multiple change agents or intrapreneurs. While social entrepreneurship occurs in start-up organizations, social intrapreneurship occurs within existing companies (Mair \& Marti, 2006; Light, 2008; Kistruck \& Beamish, 2010). The balance needs to be right between community involvement and helping the company to improve its overall social and environmental impacts through its core business activities. Organizations following the $\mathrm{CR}$ journey might encourage employees to become social intrapreneurs to successfully engage them in new activities in which CR and financial goals are much more balanced than traditional ones.

Ensuring the clear identity of specific products and services is part of the product policy in external marketing. One component of IM that is still underdeveloped is employer branding (Berthon, Ewing \& Lian Hah 2005). The difficulty of recruiting and retaining capable people encourages employers to treat their people with the same care and consideration as they would valued customers (Barrow \& Mosley, 
2005). The concept of employer branding has entered into the lexicon of management and particularly consultants, with organizations such as Versant in the US and People in Business in the UK offering specialist qualified advice in how to ensure employee loyalty and build organizational commitment (Martin, Beaumont, Doig \& Pate, 2004). It has also become an increasingly "hot topic" in the contemporary business press, and "Best Employer" status is something that more and more organizations are striving for (Berthon et al., 2005).

Following the general approach to the employer brand journey developed by Karian \& Box (2010), we recommend the following five steps for building, shaping or reinforcing a responsible employer brand:

First stage - Start with good recruitment - Aligning the people strategy with the CR strategy needs a workforce that embraces CR principles. Top employer organizations offer challenging assignments, exciting training and good development prospects, meaning they are able to recruit bright people selectively. Equally, CR companies must offer their "responsible product package" to their internal clients (current and potential employees). In addition, they have to develop clear messages about who they are and what they stand for and they must communicate it consistently. Sustainability and $C R$ is particularly relevant for engaging Generation $Y$ (Gen $Y$ ) employees. Martin (2005) has highlighted that CR is a business imperative for Gen $Y$. Gen $Y$ could be considered the cohort born between 1978 and 1988 (Martin, 2005), between 1977 and 1994 (Kim, Knight \& Crutsinger, 2009) or between 1980 and 2003 (Hurts \& Good, 2009). But, according to McCrindle (2006) the exact period considered is not important because age is just a number today. The important issue is that the new generation is aware of the urgency of responsible business and sustainability. Recruiting Gen $Y$ people might create a culture where interactions can take place, different ages can mix, and intergenerational perspectives can be shared. Mentoring is a great vehicle for values-sharing and knowledge transfer (Karallis \& Sandelands, 2009) and an important resource for learning and coping with organizational change (Rigsby, Siegel \& Spiceland, 1998). However, for sustainability purposes, rather than the traditional "older manager mentors younger employee" set-up, it is recommended genuine two-way mentoring, a win-win relationship in which the older person shares their experience and expertise while the younger can give insights into engaging with their generation and the new times (McCrindle, 2006). Bearing in mind than Gen $Y$ are advocates of social and environmental issues and sustainability, a two-way mentoring system supports the notion of capitalizing on the social tenet base and the younger perspective of the co-mentor. Thus, new 
employees could assist in transforming twentieth century managers into successful managers for the present (Harvey \& Buckley, 2002).

Second stage - Welcome to the company - Any time and effort spent making sure new employees understand the CR focus and responsible culture of the business is a good investment.

Third stage - Getting to work - An integrated approach to every aspect of employees' working experience is required to ensure the workforce remain motivated. Employees must know that $\mathrm{CR}$ is one of the business priorities. Planning a culture of open and honest communication is recommended. Leaders must set the behaviours and ways of working, demonstrating to employees that they "feel" CR principles as part of the brand.

At this stage, Volunteer Programs can help - particularly in introducing employees to a wider "menu" of ways they can help to improve the business's positive environmental and social impacts. CR programs should consider the active involvement of employees as volunteers in social and environmental projects, considering the challenges of identifying the points of intersection between CR goals and employees' social needs. Employees involved in CR projects can act both as employees in a for-profit organization, and volunteers in a not-for-profit organization (Sharp \& Zaidman, 2010). When acting as employees (in working time or inside a specific volunteer program managed by the company they work for), they represent the company and "live the company". The challenge might be to shift from employee community volunteering to a much broader empowerment and engagement with $C R$, such as opportunities to serve on green teams, be volunteer sustainability champions, propose business opportunities which simultaneously improve sustainability, or even become a social intrapreneur as we explain below. This is because organizations need to get the balance right between community involvement and helping the company to improve its overall social and environmental impacts through its core business activities (Weiser \& Zadek, 2000). Employee volunteers can, for example, take ideas and insights from businesscommunity partnerships back into the business to innovate for the business innovation through partnership.

Fourth stage - Entrenching the brand - Retaining the right employees is the key issue in entrenching the brand. That requires the best employees being recognised and rewarded for demonstrating citizenship behaviour. We refer to the creative reward packages explained above, to retain the best staff members and to engage them in the CR strategy. 
Fifth stage - The power of goodbye - Organizations can positively influence the way an ex-employee continues to engage with their former employer's brand in three main ways: exit interviews, outplacement and responsible retirement.

Exit interviews offer the company the opportunity to gather feedback from employees leaving their jobs. The information gained from these interviews enables the employer to make the necessary changes to their processes and their business to both retain and attract the best talent. It is a good opportunity to find out what is going on and can help to instigate positive change for the future at the same time that it encourages employees to think back positively about the time they worked there.

Outplacement programs usually involve career management advice, interview preparation, help on writing job applications, social networking sites, getting people to be clear on what they can offer a new employer and what they want to focus on in their next career step. Job loss is a traumatic event (Molinsky \& Margolis, 2006). Acknowledging that, organizations can include outplacement as part of their job loss policy and have a significant impact on employees' well-being and future employment potential (Hanisch, 1999).

Responsible retirement. Older employees should be considered a valuable human capital resource (Stevens, 2010), but the retirement process is not always well managed. Retired employees are an important stakeholder to be considered in the CR strategy. They have a large store of human capital from their years of training and knowledge development and they have also a large store of social capital, represented by their networks both inside and outside the company (Venneberg \& Wilkinson, 2008). Retired people will appreciate responsible organizations not ignoring the importance of this intellectual capital and failing to capitalize on it. For instance, a few companies are now starting to assume some responsibility for what happens to former employees after they have "retired" and are providing opportunities and training to prepare for a portfolio life after retirement.

\section{The price for working in a responsible company}

Changes to a CR strategy may incur costs for employees in terms of opportunity costs or psychological costs. CR efforts initially often involve extra time, sacrifices, budget changes and frequently job reassignments. Managers must take care over the internal price, as if costs are higher than utility then employees will not be interested in following the roadmap for the CR journey. Therefore, in the development of an "employees as customers" initiative (often used in IM 
programmes) great attention must be paid to the psychological aspects of the interaction and the relationship between the employee "price" and the CR actions needed. Dunne and Barnes (2000: page 205) point out that "adding value through internal relationships is to enhance the employment relationship such that the employee has the greatest potential to experience satisfying interactions, relationships and opportunities".

How to control and to reduce this cost? Improving the internal market orientation (IMO) of the organization is our suggestion. Market orientation has been defined as the organization-wide generation of market intelligence, or information on customers' current and future needs, dissemination of that information across departments, and organization-wide responsiveness to it (Kohli \& Javorski, 1990; Narver \& Slater, 1990). Consequently, IMO has been considered the philosophical base of IM (Gounaris, 2006). It refers to the company's orientation regarding its employees and is considered to be a demonstration of management's commitment towards them (Gounaris, 2008).

IMO has been defined as a tri-dimensional construct (Lings \& Greenley, 2005; Gounaris, 2006): (i) generation of labour market information and information related to current employees' needs and wants; (ii) dissemination or diffusion of that information across all organizational levels; and (iii) responsiveness to internal market intelligence. This three-component view put into practice could control and reduce employee psychological costs to embrace CR and makes it possible to detect specific problems of implementation to be corrected.

To engage employees in $C R$, you must understand the internal price on the employee's perceived value of getting involved. Effective employee collaboration in $\mathrm{CR}$ issues can only take place if the parties feel that they gain from the relationship. Gummesson (2000) recommends internal win-win relationships where employees feel they are working in an organization that gives them something back.

\section{The internal promotion}

Promotion and internal communication are vehicles for explaining to employees the CR strategy and serve to clarify their role in the development and success of the strategy. "Selling CR internally" implies making CR part of the organization's culture. The main available tools to sell CR internally are briefly described as follows.

- $C R$ internal advertising sent to employees as a whole - According to Kotler 
and Keller (2012) and adapting their advertising typology to internal clients context, goals on internally communicating $\mathrm{CR}$ could be classified as follows: Internal informative advertising aims to create employer brand awareness and knowledge of new procedures, protocols or routines related to the responsibility roadmap. Internal persuasive advertising aims to create conviction and invite employees to join the CR strategy. Internal reminder advertising for CR purposes aims to stimulate repeat citizenship behaviour, avoiding the risk that $\mathrm{CR}$ is interpreted by the workforce as a temporary fashion. Internal reinforcement advertising aims to convince employees engaged in CR that they made the right choice and they are working for the right company.

- Internal public relations and communications for key employees Companies developing a CR strategy must manage successful relations with their workforce, especially with their key employees. CR departments, or managers responsible for CR strategy, must spend time counselling top management to adopt positive communications about CR in any aspect of their day-to-day work. Some available channels are: Face-to-face communications about $\mathrm{CR}$ goals provide the opportunity to check employees' fears and resistances, in-house magazines to explain the rationale behind the changes that the $\mathrm{CR}$ strategy entails or corporate videos to emphasize that the CR strategy is supported by top management.

We are also now seeing how CEOs and country managers' webcasts and live intranet Q\&A sessions are gaining power because they are much more interactive and therefore encourage two-way communications. Innovations like IBM "jams" create opportunities for stakeholders to take the initiative and to build on other people's ideas, using the "wisdom of the crowd" (IBM, 2007).

\section{The internal place}

"Place" (in the external marketing context) is related to distribution channels and reaching targeted customers (Kotler \& Keller, 2012). In IM, "Place" is concerned with the work environment. It includes the organizational culture, values, assumptions, artefacts and every symbolic aspect of the organization (Ahmed \& Rafiq, 2003). For CR purposes "Place" can be used to draw attention to differences in employee response to CR strategic goals in order to create the best internal place for developing a CR strategy.

As organizational culture can have a huge impact on an organization's work 
environment and output, much research has been done to determine how to change this culture when necessary. Organizations might move to a responsible culture based on the premise that social and financial objectives are complementary rather than contradictory (Selsky \& Parker, 2005). The Culture Web, developed by Johnson and Scholes (1992), provides one approach for looking at and changing an organization's culture. The model identifies six interrelated elements that help to make up the paradigm of the work environment. By analysing the elements and their relationship, it is possible to imagine the bigger picture of the organizational culture, what is working and what is not and what needs to be changed in order to move to a much more responsible culture. These elements and their relation to a responsible organizational culture are:

- Stories. It is possible to manage who and what the company chooses to immortalize. Choosing past events related to sustainability champions, social issues, or ecological concerns says a great deal about what it values and perceives as great behaviour.

- Rituals and Routines. These determine what is expected to happen in given situations and what is valued by management. Moving to a responsible culture means that responsible behaviour must be understood as routine, not as an exception.

- Symbols. Coherence with CR and sustainability is needed. The visual representations of the company (including logos, how plush the offices are, and formal and informal dress codes) might be aligned with a responsible culture. For instance, ecological reminders about the rational use of paper, electricity savings, or indicating recycling areas are part of the landscape of a responsible workplace.

- Organizational Structure. These might include both the structure as defined by the organization chart, as flexible as possible to allow the existence of teams charged to enhance CR such as green teams, and the unwritten lines of power and influence indicating whose contributions to CR are most valued.

- Control Systems. The ways that the organization is controlled might consider CR goals. Beyond financial systems, quality systems and traditional rewards, responsible organizations might include sustainability considerations in their control systems. 
- Power Structures. People who have the greatest amount of influence on decisions, operations and the strategic direction of the organization might be perfectly aligned with CR and sustainability department goals.

\section{Internal segmentation and orientation for CR purposes}

Individual personal differences may entail different psychological contracts between employees and companies and different levels of engagement and advocacy as well. Internal market research should be conducted to identify the needs of employees. Traditional marketing research techniques such as simple surveys, focus groups or even complex multivariable modelling can be employed to capture a real sense of the motivations, social and environmental needs, potential barriers or fears and resistance of employees to the firm's CR journey. The next step is grouping employees into clusters as homogeneous as possible to understand the different ways needed for approaching them about the company's CR goals.

The concept of advocacy within organizations builds on employees' motivation to address, for example, social welfare problems, extra-role behaviour and social influence processes (London, 2010). High levels of advocacy characterize social entrepreneurs (Waddock, 2009).

Engagement, strongly recognized by employers as important, is more than satisfaction at work. The concept of a psychological contract is the basis of employees' engagement, emphasizing the need for organizations to win employees' hearts and minds (Guest \& Conway, 2004). A narrow conceptualization of engagement measures factors such as employee commitment and organizational citizenship and the concept of full engagement adds the aspect of positive psychological well-being, which focuses on the benefits that engagement delivers for employees (Robertson \& Cooper, 2010).

Our proposal is to segment employees on these two criteria, the degree of employee advocacy understood as social and environmental active support and the level of full engagement considering commitment, organizational citizenship behaviour and well-being. This gives a four quadrant matrix (Figure 2) where each employee can be rated as:

- "Exemplars": Employees who are highly engaged and have a strong understanding of the organization's CR goals and what it stands for. Retaining and increasing their number is the challenge. New employees such as Gen $Y$ employees have the possibility to become "Exemplars" if a 
responsible organization engages with them and supports their ideas and suggestions - enhancing their desire to change the status quo.

- "Gatekeepers": Employees who are emotionally disengaged but have a high level of active support for CR concerns. The challenge is to show these employees that they gain from the relationship with the organization. Engagement improves they realize that the organization represents their social motivations.

- "Triers": Employees who are engaged whilst having a relatively weak understanding of the CR goals. They could be Gen X or even older workers with high levels of human and social capital but not very interested in sustainability. Managing human capital is the answer and reverse mentoring might help to use knowledge management to transfer any kind of knowledge in this multigenerational workforce.

- "Blockers": Employees who are emotionally disengaged and not motivated to address CR issues. This is the worst situation for all. Recruitment could have mistakenly matched incompatible employee-employer and consequently retention will be difficult to maintain.

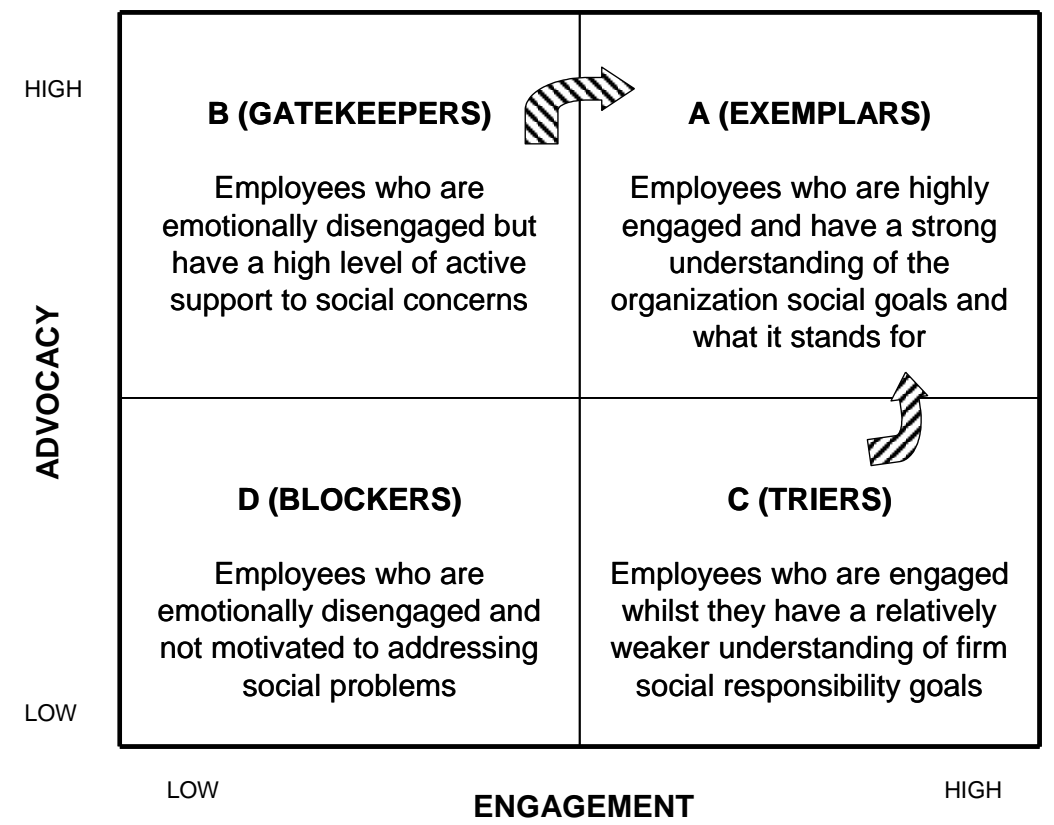

Figure 2. Employee Segmentation for CR purposes

How does one practically approach these segments and determine who is in each one? Questionnaires, surveys, workshops and interviews with a cross-section of managers, staff and employees as a whole will provide the required information to 
appreciate the differences and to help design specific ways of motivating targeted segments toward CR consciousness. At this point it is important to remark that information obtained from internal clients must be already used for segmentation purposes. The fact is that traditionally there is a lack of internal market research in companies and, when existing, Human Resources, Marketing Department, or both can be overly secretive but that must change.

\section{Discussion and management implications}

Today, CR strategies should work towards rewarding business, society and the environment - these benefits should be mutually inclusive. The case for incorporating social and environmental issues into corporate strategy is overwhelming. Done well it can create opportunities that companies benefit from (Bonini, Mendoca \& Oppenheim, 2006). To win in the social capital market, organizations must transcend the traditional way of thinking where just "not doing bad" (compliance) is enough, or just doing good (as philanthropy) is good enough. Stakeholders in the social capital market have a much higher set of expectations from business, looking for organizations to proactively solve social problems in a way that meets its responsibilities to the organization's owners (Saul, 2010). This requires innovative approaches to doing business, one where it is critical that an organization's employees are involved and have the right skills. Embedding CR into employees' mindset and actions through IM could be a first step in developing this innovative approach to sustainability.

Strong and committed top management support and an integrated effort for interfunctional co-ordination are critical factors for CR performance. A point of interest that needs to be highlighted is that engaging employees regarding the CR journey is not solely the responsibility of the Human Resources or the Marketing or the CR departments in isolation. A critical issue for many organizations is the extent to which the different functional areas are integrated and are capable of coordinating their efforts in order to reach organizational goals. To accomplish the CR agenda, it is recommended using cross-functional teams in the development and running of an IM program for this purpose.

An IM Plan, supported by an already-established internal market orientation, can help to enhance the process by which the CR strategy is internalized within the organization creating dynamic capabilities likely to lead to competitive advantage. Table 1 resumes the new offers explained, indicating whether they are routines, mechanisms or job characteristics to be developed and the group of employees 
affected by the new offer. In the context of CR strategy implementation, some management implications arise when an organisation is oriented to the internal market and understands the relevance of IM programs.

In the first place, managers can influence the behaviour of their employees, making them more motivated and committed to recognizing the significance of participating in a responsible organization. Such an approach needs to understand that $C R$ should start with employees. As the employee base is made up of many, many individuals, identifying the nature of employees' needs and wants and how these needs can be satisfied by the organization through the development of human resources policies, is a big challenge. Asking employees how they feel they are being treated and what is the work reality that they are living in could be the starting point for building an appropriate culture for CR.

In this sense, the second implication refers that IM can be used by managers to create and disseminate $C R$ values throughout the organization. Managers must be an example for employees and must enhance internal communications to encourage a culture of corporate citizenship behaviour whilst also ensuring job satisfaction and retention.

The third implication, in order to ensure successful implementation of IM plans for CR purposes, it is recommended that the relevant CR (or Internal Communication or HR) managers are trained in IM tools such as internal market research and segmentation, internal communications or internal selling actions.

In the fourth place, engaging employees in volunteering programs and becoming an employer of choice could help the organization make progress to its broader CR goals.

And finally, the fifth implication, in order to get the right balance between community or environmental involvement and helping the company to improve its overall social and environmental impacts through its core business activities, managers might create opportunities for employees to either become a member of the $\mathrm{CR} /$ sustainability team or get visually involved from their own department.

Broadly speaking, this study suggests that IM can help managers to discover and take profit from the social and environmental potential of employees, helping the CR team to integrate employees' interest and skills into the overall CR efforts.

The framework developed in this study shows a promising area in which to focus empirical evidences and further conceptual research efforts. While this task is left 
for future research, we believe that this paper has made a contribution to how and

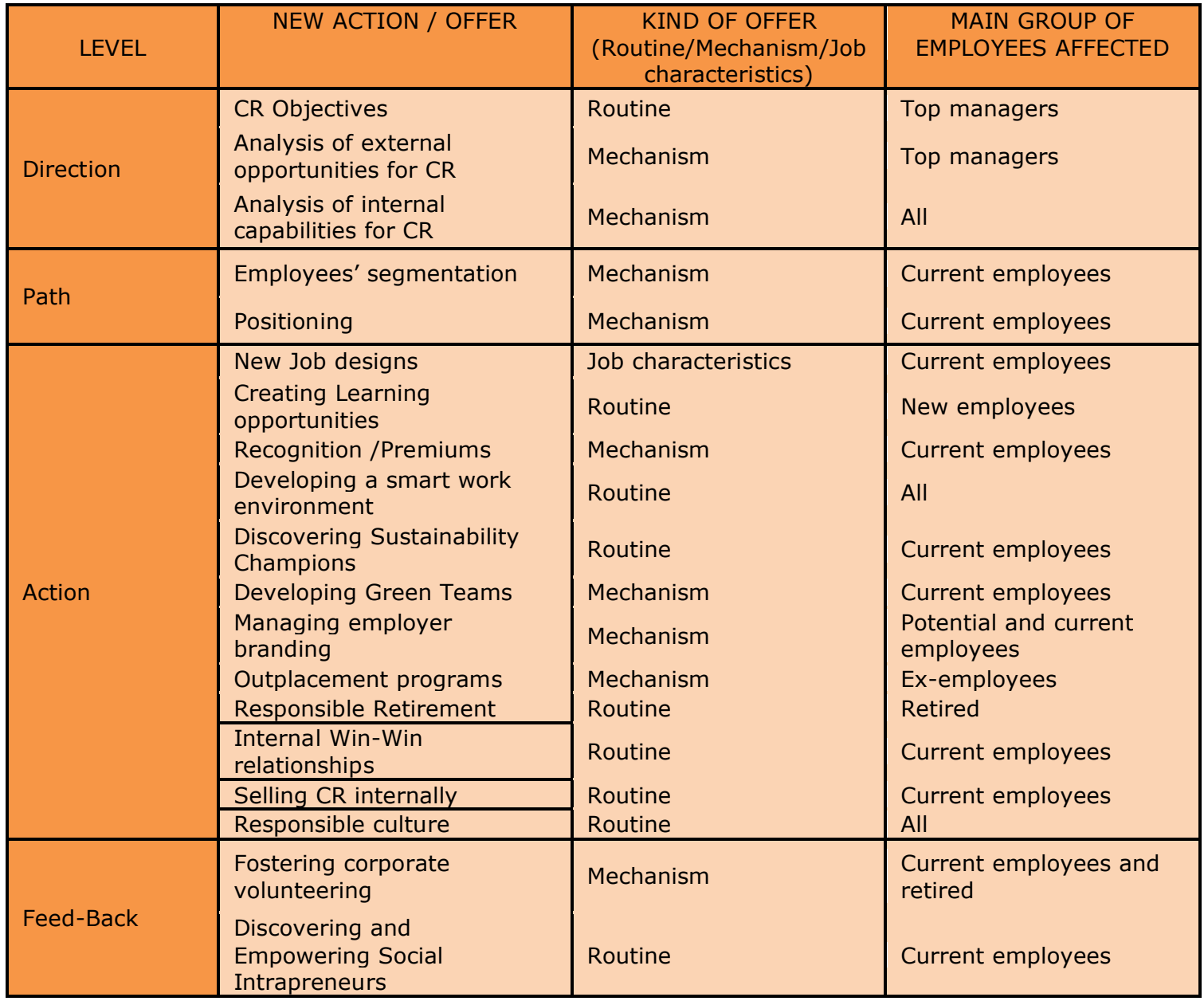

where this future research could start.

Table 1. New possibilities of the organization to generate a sustainable advantage related to CR capabilities

\section{References}

ACKERMAN, N.; HELLIWELL, S.; NISENSON, J.; PATTINSON, T.; LATIMER, L.; QUEVEDO, E.L. (2010). Generating sustainable value: Moving beyond green teams to transformation collaboratives. Dominican University of California: Sabre Holdings.

AHMED, P.K.; RAFIQ, M. (1993). The scope of internal marketing: Defining the boundary between marketing and human resource management. Journal of Marketing Management, 9(3): 219-232. http://dx.doi.org/10.1080/0267257X.1993.9964234 
AHMED, P.K.; RAFIQ, M. (2002). Internal Marketing - Tools and concepts for customer-focused management. Oxford: Butterworth-Heinemann Publications.

AHMED, P.K.; RAFIQ, M. (2003). Commentary: Internal marketing issues and challenges. European Journal of Marketing, 37(9): 1177-1186. http://dx.doi.org/10.1108/03090560310498813

AHMED, R.K.; RAFIQ, M. (1993). The scope of internal marketing: defining the boundary between marketing and human resource management. Journal of Marketing Management, 9: 219-232. http://dx.doi.org/10.1080/0267257X.1993.9964234

AMA - AMERICAN MARKETING ASSOCIATION (2007). Definition of Marketing http://www.marketingpower.com/AboutAMA/Pages/DefinitionofMarketing.aspx - Accessed April 2012.

ARNETT, D.; LAVERIE, D.; McLANE, C. (2002). Using job satisfaction and pride as internal-marketing tools. Cornell Hotel and Restaurant Administration Quarterly, April: 88-96.

AUSTIN, J.; REFICCO, E. (2009). Corporate Social Entrepreneur, Working Paper, Harvard Business School.

BAGNOLI, M.; WATTS, S. (2003). Selling to socially responsible consumers: Competition and the private provision of public goods. Journal of Economics and Management Strategy, 12(3): 419-445. http://dx.doi.org/10.1162/105864003322309536

BALLANTYNE, D. (1997). "Internal networks for internal marketing". Journal of Marketing Management, 13: 343-366. http://dx.doi.org/10.1080/0267257X.1997.9964479

BANSAL, H.S.; MENDELSON, M.B.; SHARMA, B. (2001). The impact of internal marketing activities on external marketing outcomes. Journal of Quality Management, 6: 61-76. http://dx.doi.org/10.1016/S1084-8568(01)00029-3

BARNES, B.R.; MORRIS, D.S. (2000). Revising quality awareness through internal marketing: An exploratory study among French and English medium-sized enterprises. Total Quality Management, 11(4/5\&6): 473-483.

BARNEY, J. (1991). Firm resource and sustained competitive advantage. Journal of Management, 17: 99-120. http://dx.doi.org/10.1177/014920639101700108

BARROW, S.; MOSLEY, R. (2005). The employer brand. Bringing the best management to people at work. Chichester: John Wiley and Songs. 
BARTLETT, D. (2009). Embedding corporate social responsibility: The development of a transformational model of organizational innovation. Corporate Governance, 9(4): 409-420. http://dx.doi.org/10.1108/14720700910984963

BEARD, C.; REES, S. (2000). Green teams and the management of environmental change in a UK county council. Environmental Management and Health, 11(1): 27-38. http://dx.doi.org/10.1108/09566160010314161

BERRY, L.L. (1981). The employee as customer. Journal of Retail Banking, 3(March): 25-28.

BERTHON, P.; EWING, M.; LIAN HAH, L. (2005). Captivating company: Dimensions of attractiveness in employer branding. International Journal of Advertising, 24(2): 151-172.

BHATTACHARYYA, S.S. (2010). Exploring the concept of strategic corporate social responsibility for an integrated perspective. European Business Review, 22(1): 82-101. http://dx.doi.org/10.1108/09555341011009025

BIES, R.J.; BARTUNEK, J.M.; FORT, T.L.; ZALD, M.N. (2007). Corporations as social change agents: Individual, Interpersonal, institutional, and environmental dynamics. Academy of Management Review, 32(3): 788-793. http://dx.doi.org/10.5465/AMR.2007.25275515

BITC - Business in the Community (2009). The responsible workplace. How to survive and thrieve, www.bitc.org.uk - Accessed April 2012.

BLOOM, P.N.; GUNDLACH, G.T. (2001). Handbook of Marketing and Society. Sage Publications, Inc., Thousand Oaks, C.A.

BONINI, S.M.J.; MENDOCA, L.T.; OPPENHEIM, J.M. (2006). When social issues become strategic. McKeinsey Quarterly, 2: 19-31.

BOUDREAU, J.; RAMSTAD, P. (2005). Talenship, talent segmentation, and sustainability: A new HR decision science paradigm for a new strategy definition. Human Resource Management, 44(2): 129-136. http://dx.doi.org/10.1002/hrm.20054

BOUZAS-LORENZO, R. (2010). Public Sector marketing, political science and the science of public administration: The evolution of transdisciplinary dialogue. International Review on Public and Nonprofit Marketing, 7(2): 113-125. http://dx.doi.org/10.1007/s12208-010-0057-2 
CARROLL, A.B. (1979). A three-dimensional conceptual model of corporate social performance. Academy of Management Review, 4(4): 497-505.

CARROLL, A.B. (1991). The pyramid of corporate social responsibility toward the moral management of organizational stakeholders. Business Horizons, JulyAugust: 39-48. http://dx.doi.org/10.1016/0007-6813(91)90005-G

CLARKSON, M. (1995). A stakeholder framework for analyzing and evaluating corporate social performance. Academy of Management Review, 20(1): 92-117.

COLLINS, B.; PAYNE, A. (1991). Internal marketing: A new perspective for HRM. European Management Journal, 9(3): 261-270. http://dx.doi.org/10.1016/02632373(91)90006-C

CHAPMAN D.; COWDELL T. (1998). New public sector marketing. Financial Times Pitman Publications.

DUNNE, P.A.; BARNES, J.G. (2000). Internal marketing. A relationships and valuecreation view. In R.J. Varey (Ed), Internal Marketing: Directions for Management. London, UK: Routledge: 192-220. http://dx.doi.org/10.4324/9780203207352.ch12

ELKINGTON, J. (1998). Cannibals with forks: The triple bottom line of 21st century business. Gabriola Island, BC Canada: New Society Publishers.

EUROPEAN COMMISSION (2011). A renewed EU strategy 2011-14 for Corporate Social Responsibility, available at: http://ec.europa.eu - Accessed 3 April 2012.

EWING, M.; CARUANA, A. (1999). An internal marketing approach to public sector management. The marketing and human resources interface. The International Journal of Public Sector Management, 12(1): 17-26. http://dx.doi.org/10.1108/09513559910262652

EXTER, N (2009). Corporate responsibility champions network: A "how to" guide, doughty centre for corporate responsibility.

FERNANDEZ, E.; MONTES, J.M.; VAZQUEZ, C.J. (2000). Typology and strategy analysis of intangible resources. A resource-based approach. Technovation, 20: 81-92. http://dx.doi.org/10.1016/S0166-4972(99)00115-7

FERNANDEZ-KRANZ, D.; SANTALÓ, J. (2010). When necessity becomes a virtue: The effect of product market competition on corporate social responsibility. 
Journal of Economics and Management Strategy, 19(2): 453-487. http://dx.doi.org/10.1111/j.1530-9134.2010.00258.x

FONTENEAU, G. (2003). Corporate social responsibility: Envisioning its social implications. Working Paper (October), The living wages North and South initiative: 1-11.

FREEMAN, R. E. (1984). Strategic Management: A stakeholder approach. Boston: Pitman.

GALBREATH, J. (2006). Corporate social responsibility strategy: Strategic options, global considerations. Corporate Governance, 6(2): 175-187. http://dx.doi.org/10.1108/14720700610655178

GEORGE, W.R. (1990). Internal marketing and organizational behavior: A partnership in developing customer-conscious employees at every level. Journal of Business Research, 20: 60-70. http://dx.doi.org/10.1016/0148-2963(90)90043-D

GIROD, S.J.G. (2005). The human resource management practice of retail branding. International Journal of Retail and Distribution on Management, 33(7): 514-530. http://dx.doi.org/10.1108/09590550510605587

GOUNARIS, S. (2006). Internal market orientation and its measurement. Journal of Business Research, 59: 432-448. http://dx.doi.org/10.1016/j.jbusres.2005.10.003

GOUNARIS, S. (2008). The notion of internal market orientation and employee job satisfaction: Some preliminary evidence. Journal of Services Marketing, 22(1): 68-90. http://dx.doi.org/10.1108/08876040810851978

GRAYSON, D. (2010). Can CSR engage employees?. Strategic HR Review, 9(3), Q\&A.

GRÖNROOS, C. (1981). Internal marketing - an integral part of marketing theory. In J.H. Donnelly \& W.R. George (Eds.), Marketing of Services (pp. 236-238). American Association Proceedings Series.

GUEST, D.; CONWAY, N. (2004). Employee well-being and the psychological contract. London: CIPD.

GUMMESSON, E. (2000). Internal marketing in the light of relationship marketing and network organizations, In R.J. Varey \& B.R. Lewis (Eds.), Internal Marketing: 
Directions for Management, 27-42. New York, Routledge. http://dx.doi.org/10.1108/17566691011026577

GUMMESSON, E.; LUSCH, R.F.; VARGO, S.L. (2010). Transitioning from service management to service-dominant logic. Observations and recommendations. International Journal of Quality and Service Science, 2(1): 8-22.

GUNDLACH, G.T. (2007). The American Marketing Association's 2004 definition of marketing: Perspectives on its implications for scholarship and the role and responsibility of marketing in society. American Marketing Association, 26(2)Fall: 243-250.

HANISCH, K.A. (1999). Job loss and unemployment research from 1994 to 1998: A review and recommendations for research and intervention. Journal of Vocational Behavior, 55: 188-220. http://dx.doi.org/10.1006/jvbe.1999.1722

HARVEY, M.; BUCKLEY, M.R. (2002). Assessing the conventional wisdoms of management for the $21^{\text {st }}$ century organization. Organizational Dynamics, 30(4): 368-378. http://dx.doi.org/10.1016/S0090-2616(02)00062-1

HURTS J.L.; GOOD, L.K. (2009). Generation $Y$ and career choice. The impact of retail career perceptions, expectations and entitlement perceptions. Carrier Development International, 14(6): 570-593. http://dx.doi.org/10.1108/13620430910997303

IBM (2007). Tapping into collective intelligence: how to leverage the wisdom of the crowd to boost the bottom line, June. http://www-935.ibm.com/services - Accessed September 2010.

JOHNSON G.; SCHOLES, K. (1992). Exploring corporate strategy. Prentice Hall.

KAPLAN, S.L. (2007). Business strategy, people strategy and total rewards. Benefits \& Compensation Digest, 44(9) September: 12-19.

KARALLIS, T.; SANDELANDS, E. (2009). Making mentoring stick: A case study. Education and Training, 51(3): 203-209. http://dx.doi.org/10.1108/00400910910960731

KARIAN \& BOX Inc. (2010). A guide to employer branding, http://www.karianandbox.com Accessed August 2010. 
KIM, H.J.; KNIGHT, D.K.; CRUTSINGER, C. (2009). Generation Y employees' retail work experience: The mediating effect of job characteristics. Journal of Business Research, 62: 548-556. http://dx.doi.org/10.1016/j.jbusres.2008.06.014

KISTRUCK, G.M.; BEAMISH, P.W. (2010). The Interplay of form, structure, and embeddedness in social intrapreneurship. Entrepreneurship Theory and Practice, July: 735-761. http://dx.doi.org/10.1111/j.1540-6520.2010.00371.x

KOCH, M.J.; McGRATH, R.G. (1996). Improving Labor Productivity: Human Resource Management Policies do Matter. Strategic Management Journal, 17: 335-354. http://dx.doi.org/10.1002/(SICI)1097-0266(199605)17:5<335::AID-SMJ814>3.0.CO;2-R

KOHLI A.; JAWORSKI B. (1990). Market orientation: The construct, research propositions, and managerial implications. Journal of Marketing; 54(2): 1-18. http://dx.doi.org/10.2307/1251866

KOTLER, P. (1972). A generic concept of marketing. Journal of Marketing, 36(April): 345-354.

KOTLER, P.; AMSTRONG, G. (2008). Principles of Marketing, (12 ${ }^{\text {th }}$ Ed.). New Jersey: Prentice Hall.

KOTLER, P.; KELLER, K. L. (2012). Marketing Management, (14 ${ }^{\text {th }}$ Ed.). New Jersey: Pearson-Prentice Hall.

LIGHT, P. (2008). The search for social entrepreneurship. Washington, DC: The Brookings Institution.

LINGS I.; GREENLEY, G. (2005). Measuring internal market orientation. Journal of Services Research; 7(3): 290-305. http://dx.doi.org/10.1177/1094670504271154

LONDON, M. (2010). Understanding social advocacy: An integrative model of motivation, strategy, and persistence in support of corporate social responsibility and social entrepreneurship. Journal of Management Development, 29(3): 224245. http://dx.doi.org/10.1108/02621711011025768

MAIR, J.; MARTI, I. (2006). Social entrepreneurship research: A source of explanation, prediction, and delight. Journal of World Business, 41: 36-44. http://dx.doi.org/10.1016/j.jwb.2005.09.002 
MARTIN, C.A. (2005). From high maintenance to high productivity. What managers need to know about generation Y. Industrial and commercial training, 37(1): 3944. http://dx.doi.org/10.1108/00197850510699965

MARTIN, G.; BEAUMONT, P.; DOIG, R.; PATE, J. (2004). Branding: A new performance discourse for HR?. European Management Journal, 23(1): 76-88. http://dx.doi.org/10.1016/j.emj.2004.12.011

MAXFIELD, S. (2008). Reconciling corporate citizenship and competitive strategy: Insights from economic theory. Journal of Business Ethics, 80: 367-377. http://dx.doi.org/10.1007/s10551-007-9425-1

McBAIN, R. (2007). The practice of engagement. Strategic Human Resources Review, 6(6): 16-19.

McCARTHY, E.J. (1960). Principles of Marketing, Irwin Publishing.

MCCRINDLE, M. (2006). New generations at work: Attracting, recruiting, retaining Generation Y. Australia: Mccrindle Research.

MINTZBERG, H. (1979). The structuring of organizations. Prentice-Hall, Englewood Cliffs.

MOLINSKY, A.; MARGOLIS, J. (2006). The emotional tightrope of downsizing: Hidden challenges for leaders and their organizations. Organizational Dynamics, 35(2): 145-59. http://dx.doi.org/10.1016/j.orgdyn.2006.03.005

NARVER, J.; SLATER, S. (1990). The effect of a market orientation on business profitability. Journal of Marketing, 54(4): 20-35. http://dx.doi.org/10.2307/1251757

PIERCY, N.; MORGAN, N. (1991). Internal marketing - the missing half of the marketing programme. Long Range Planning, 24(2): 82-93. http://dx.doi.org/10.1016/0024-6301(91)90083-Z

PORTER, M.E.; KRAMER, M.R. (2006). The link between competitive advantage and corporate responsibility. Harvard Business Review, 84(12): 78-92.

PRAHALAD, C.K.; HAMEL, G. (1990), The core competence of the corporation. Harvard Business Review, May/June: 79-91.

RIGSBY, J.T.; SIEGEL, P.H.; SPICELAND, J.D. (1998). Mentoring among management advisory services professionals: An adaptive mechanism to cope 
with rapid corporate change. Managerial Auditing Journal, 13(2): 107-116. http://dx.doi.org/10.1108/02686909810202809

ROBERTSON, I.T.; COOPER, C.L. (2010). Full engagement: The integration of employee engagement and psychological well-being. Leadership and Organization Development Journal, 31(4): 324-336. http://dx.doi.org/10.1108/01437731011043348

SANCHEZ-HERNANDEZ, M.I. (2008). Internal marketing as a factor of success in new service development: An empirical approach. International review on public and nonprofit marketing, 5: 81-82.

SANCHEZ-HERNANDEZ, M.I.; MIRANDA, F.J. (2011). Linking internal market orientation and new service performance. European Journal of Innovation Management, 14(2): 207-226. http://dx.doi.org/10.1108/14601061111124894

SAUL, J. (2010). Social Innovation, INC. Strategies for driving business growth through social change. San Francisco: Jossey-Bass.

SELSKY, J.W.; PARKER, B. (2005). Cross-sector partnerships to address social issues: Challenges to theory and practice. Journal of Management, 31: 849-873. http://dx.doi.org/10.1177/0149206305279601

SHARMA, S.; VREDENBURG, H. (1998). Proactive environmental strategy and the development of competitively valuable organizational capabilities. Strategic Management Journal, 19(8): 729-753. http://dx.doi.org/10.1002/(SICI)10970266(199808)19:8<729::AID-SMJ967>3.0.CO;2-4

SHARP, Z.; ZAIDMAN, N. (2010). Strategization of CSR. Journal of Business Ethics, 93: 51-71. http://dx.doi.org/10.1007/s10551-009-0181-2

SIMMONS, J.A. (2009). Both sides now: Aligning external and internal branding for a socially responsible era. Marketing Intelligence \& Planning, 27(5): 681-697. http://dx.doi.org/10.1108/02634500910977890

SIRGY, M.J.; LEE, D.J. (2008). Well-being marketing: An ethical business philosophy for consumer goods firms. Journal of Business Ethics, 77: 377-400. http://dx.doi.org/10.1007/s10551-007-9363-y

STEVENS, R.H. (2010). Managing human capital: How to use knowledge management to transfer knowledge in today's multi-generational workforce. International Business Research, 3(3): 77-83. 
TEECE, D.J.; PISANO, G.; SHUEN, A. (1997). Dynamic capabilities and strategic management. Strategic Management Journal, 18(7): 509-533. http://dx.doi.org/10.1002/(SICI)1097-0266(199708)18:7<509::AID-SMJ882>3.0.CO;2-Z

TOWERS PERRIN, Inc. (2007). Using total rewards to build and effective employee value proposition, http://www.towersperrin.com - Accessed September, 2010.

VARGO, S.L.; LUSCH, R.F. (2004). Evolving to a new dominant logic for marketing. Journal of Marketing, 68(1): 324-335. http://dx.doi.org/10.1509/jmkg.68.1.1.24036

VENNEBERG, D.L.; WILKINSON, V.D. (2008). "Retirees who returned to work: Human and social capital implications for organizations". Journal of workplace behavioural health, 23(1): 1-15. http://dx.doi.org/10.1080/15555240802188358

WADDOCK, S. (2009). Difference makers as social entrepreneurs. Organizational Dynamics, 38(4): 281-289. http://dx.doi.org/10.1016/j.orgdyn.2009.07.007

WALSH, J.P. (2005). Book review essay: Taking stock of stakeholder culture. Academy of Management Review, 30(2): 426-438. http://dx.doi.org/10.5465/AMR.2005.16387898

WCED (1987). Our Common Future (the Brundtland Report), Oxford: Oxford University Press.

WEBSTER, F.E. Jr. (2005). Evolution of marketing management. Journal of Public Policy Marketing, 24: 121-126. http://dx.doi.org/10.1509/jppm.24.1.121.63888

WEISER, J.; ZADEK, S. (2000). Conversations with disbelievers: The business case for corporate social responsibility. New York: Brody \& Weiser for the Ford Foundation.

WERE, M. (2003). Implementing corporate responsibility. The Chiquita case. Journal of Business Ethics, 44: 247-260. http://dx.doi.org/10.1023/A:1023316303587

WERNERFELT, B. (1984). A resource and sustained competitive advantage. Journal of Management, 5: 171-180.

WILKIE, W.L.; MOORE, E.S. (2003). Scholarly research in marketing: Exploring the "4 Eras" of Thought development". Journal of Public and Policy Marketing, 22(Fall): 116-146. http://dx.doi.org/10.1509/jppm.22.2.116.17639

WOOD, D. (1991). Corporate social performance revisited. Academy of Management Review, 16(4): 691-718. 
WOODRUFFE, H. (1995). Services Marketing. Pearson Professional Ltd.

Intangible Capital, 2012 (www.intangiblecapital.org)

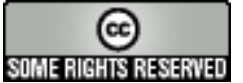

Article's contents are provided on a Attribution-Non Commercial 3.0 Creative commons license. Readers are allowed to copy, distribute and communicate article's contents, provided the author's and Intangible Capital journal's names are included. It must not be used for commercial purposes. To see the complete licence contents, please visit http://creativecommons.org/licenses/by-nc/3.0/es/ 